\title{
THE EFFECT OF DIFFERENT CARBOHYDRATE AND NITROGEN SOURCES ON THE UTILIZATION OF AMINO ACIDS IN THE SMALL INTESTINE OF SHEEP
}

\author{
N.H. Lee ${ }^{1}$ and D.G. Armstrong ${ }^{2}$ \\ Korea Food Research Institute, c/o KIST P.O. Box 131 \\ Dong Dae Mun, Seoul, Korea
}

Summary

\begin{abstract}
This experiment was conducted to examine the effects of different carbohydrate and nitrogen source upon the utilization of amino acids in the small intestine of sheep.

The results obtained are as follows:

1) For the quantities of total amino acid-N(TAA-N), essential amino acid-N(EAA-N) and nonessential amino acid-N(NEAA-N) passing at the duodenum and ileum except NEAA-N passing at the ileum were no significant differences $(\mathrm{p}>0.05)$ between diets. The quantities of NEAA-N passing at the ileum for the diets containing meat and bone meal were significantly higher $(p>0.05)$ than the diets containing soyabean meal. The mean values for the proportionate disappearance apparently digested TAA-N, EAA-N and NEAA-N within the small intestine for four diets were $0.692 \pm 0.0449,0.702 \pm 0.0132$ and $0.682 \pm 0.726$, respectively.

2) There were no significant differences $(p>0.05)$ in duodenal individual amino acid flow between diets with the exception of aspartic acid and glycine. The amounts of each amino acid in duodenal digesta, expressed as a proportion of the amounts ingested for the four diets, were shown that there were net gains of EAA with the exception of arginine and NEAA with the exception of glutamic acid, glycine and proline prior to the small intestine.

3) Within the small intestine, there were no significant losses of each EAA $(p>0.05)$ but significant losses of aspartic acid and glycine of NEAA between diets $(\mathrm{p}<0.01)$. The mean values of the proportionate losses of methionine, alanine and lysine within the small intestine were $0.816 \pm 0.04,0.767 \pm$ 0.04 and $0.732 \pm 0.01$, respectively.
\end{abstract}

(Key Words: Carbohydrate Sources, Nitrogen Sources, Utilization of Amino Acids, Small Intestine)

\section{Introduction}

The aim of feeding different protein sources of undegrable protein to ruminants is usually to increase the amount of total amino acids being made available for digestion in the small intestine. Direct measurements of the flow of amino acids into the proximal intestine can be obtained when the protein being investigated in fed to animals equipped with duodenal and ileal re-entrant cannulae (McMeniman and Armstrong, 1979).

It is very important to understand the protein degradability of protein sources and utilization of amino acids in forestomach, small intestine and

\footnotetext{
${ }^{1}$ Address reprint requests to Dr. N.H. Lee, Korea Food Research Institute, c/o KIST P.O. Box 131, Dong Dae Mun, Seoul, Korea.

${ }^{2}$ University of Newcastle Upon Tyne, England.

Received August 5, 1989

Accepted May 7, 1990
}

hindgut. Meat and bone meal is good source for undergradable protein and soyabean oil meal contains easily degradable protein. Barley is using as common energy source in Europe and maize is using in USA and Far East as major ingredient of feed formulation. However, there is very limited data on the effect of protein degradability and utilization of amino acids on the barley or maize base diet with low quality roughages.

This experiment was conducted to examine the effects of different carbohydrate source and nitrogen source upon the utilization of amino acids in the small intestine in sheep given diets containing grains and alkali treated barley straw.

\section{Materials and Methods}

\section{Experimental animal}

Four male sheep (Suffolk $X$ Halfbred, $40 \mathrm{~kg}$ ) were used. Each sheep was fitted with a rumen cannula, and with re-entrant cannulae at both the proximal duodennum and terminal ileum, using 
the technique of Brown, Armstrong and MacRac (1968). Temperature in the animal house was maintained at $14-16^{\circ} \mathrm{C}$, and the lighting, which was controlled by an automatic time switch, was on for $14 \mathrm{~h} /$ day unless a sample collection was in progress, in which case it was left on continuously. The cannulae were inspected daily and cleaned. Prior to an experimental period, the animals were gradually adapted to any new diet over a period of not less than one week. In the experiment here the animals were fed twice daily at 08:00 and 16:00 h.

\section{Experimental diets}

The four diets consisted of barley-meat and bone meal(Diet A), barley-soyabean mean(Deat B), maize-meat and bone meal(Diet C), and maizesoyabean meal(Diet D). Alkali treated barley straw pellet was used as commercial product. The quantities of each feeding-stuff fed daily to sheep are shown in table 1. Diets contained vitamin and trace mineral supplements, chromic oxide for indicator and molasses for binder. These diets were fed at $1.25 \times$ maintenance of metabolizable energy (ME).

\section{Experimental design}

The experiment consisted of four dietary periods. The first period, each of 25 days, took the form of a $4 \times 4$ latin square.

\section{Collection and sampling}

Faecal and digesta samples were collected and prepared for analysis by the method described by Beever et al (1971). Faecal and urinary collections were made for a period of 7 days and were followed by 24 hour total collections, first of ileal and then of duodenal digesta (McMeniman and Armstrong, 1979). Flows of duodenal and ileal digesta were corrected for $100 \%$ recovery of chromic oxide (MacRae and Armstrong, 1969).

\section{Chemical analysis}

The methods used to determine the amino acid contents were as described by McMemiman and Armstrong (1979) except that a Locarte Amino Acid Analyzer (Locarte Scientific Instru-

TABLE 1. THE QUANTITIES OF EACH FEEDINGSTUFF FED DAILY (G)

\begin{tabular}{|c|c|c|c|c|}
\hline Feedingstuff & $\begin{array}{c}\text { Diet A } \\
\text { Barley-meat }\end{array}$ & $\begin{array}{c}\text { Diet B } \\
\text { Barley-soya }\end{array}$ & $\begin{array}{c}\text { Diet C } \\
\text { Maize-meat }\end{array}$ & $\begin{array}{c}\text { Diet D } \\
\text { Maize-soya }\end{array}$ \\
\hline Barley straw pellet & 172.71 & 169.85 & 164.16 & 161.20 \\
\hline Barley & 465.50 & 452.43 & - & - \\
\hline Maize & - & - & 353.88 & 349.59 \\
\hline Soyabean meal & - & 69.70 & - & 66.29 \\
\hline Meat and bone meal & 71.72 & - & 67.10 & - \\
\hline $\mathrm{Cr}_{2} \mathrm{O}_{3}$ & 1.37 & 1.38 & 1.25 & 1.30 \\
\hline Binder (molasses) & 26.86 & 26.10 & 67.36 & 44.08 \\
\hline Trace mineral supplements & + & + & + & + \\
\hline $\mathrm{ME}$ of $\operatorname{diet}(\mathrm{MJ} / \mathrm{kg})$ & 12.22 & 12.42 & 13.93 & 14.14 \\
\hline Crude protein $(\%)$ & 12.91 & 12.68 & 12.31 & 12.36 \\
\hline \multicolumn{5}{|c|}{ (1) Trace mineral supplements ( $\mathrm{g} / 100 \mathrm{~kg}$ diet) } \\
\hline $\mathrm{FeSO}_{4} \cdot 7 \mathrm{H}_{2} \mathrm{O} \quad(\mathrm{g})$ & 11.05 & 11.48 & 12.88 & 13.49 \\
\hline $\mathrm{MnSO}_{4} \cdot 4 \mathrm{H}_{2} \mathrm{O} \quad(\mathrm{g})$ & 9.39 & 9.74 & 10.88 & 11.40 \\
\hline $\mathrm{Na}_{2} \mathrm{~B}_{4} \mathrm{O}_{7} \cdot 10 \mathrm{H}_{2} \mathrm{O}(\mathrm{g})$ & 7.40 & 7.66 & 8.53 & 9.05 \\
\hline $\mathrm{KI} \quad(\mathrm{mg})$ & 56.55 & 59.16 & 66.12 & 69.60 \\
\hline $\mathrm{ZnSO}_{4} \cdot 5 \mathrm{H}_{2} \mathrm{O}$ & 1.25 & 1.30 & 1.45 & 1.52 \\
\hline $\mathrm{CoCl}_{4}$ & 15.92 & 16.49 & 18.45 & 19.41 \\
\hline $\mathrm{Na}_{2} \mathrm{MoO}_{4} \cdot 2 \mathrm{H}_{2} \mathrm{O} \quad(\mathrm{mg})$ & 10.81 & 11.19 & 12.52 & 13.17 \\
\hline Choline chloride & 96.67 & 100.10 & 112.05 & 117.85 \\
\hline Robimix $\mathrm{AD}_{3}$ & 233.13 & 241.43 & 270.23 & 284.22 \\
\hline Robimix E & 3.09 & 3.21 & 3.59 & 3.78 \\
\hline
\end{tabular}


ments, London) was used.

The dry matter and organic matter, nitrogen and ammonia nitrogen contents of the feedingstuffs, faeces and urine samples were determined by the methods of McMeniman and Armstrong (1979). The chromic oxide contents of freezedried duodenal digesta and ileal digesta and diets were determined by atomic absorption spectrophotometry(Pye Unicam Ltd. Cambridge, England) after digestion with a potassium bromideacid mix ture (Williams et al., 1962).

\section{Results and Discussion}

The data for the quantities of organic matter present in the feed and faeces and passing at the proximal duodenum and terminal ileum of sheep are shown in table 2 . There were significant differences between diets in the quantities of organic matter (OM) passing at the proximal duodenum and terminal ileum $(p<0.05)$ and in the faeces $(p<0.05)$. This was probably due to the difference between intakes. Dry matter intakes were not equal for all diets. This was an unavoidable result of adjusting diets for similar total metabolizable energy intake (Maintenance $X 1.25$ ). However, there were no significant differences between diets in the apparently digested OM disappearing before the small intestine and in the whole tract. The mean values for apparent OM digestibility and the proportion of the apparently digested OM disappearing prior to and within the small intestine for four diets were $0.8246 \pm 0.0168,0.6717 \pm$ 0.0238 and $0.2351 \pm 0.0247$, respectively. The proportionate loss of OM within the caecum and colon for four diets were $0.0932 \pm 0.0142$ of mean values.

Table 3 gives the results relating to flows of total $\mathrm{N}$ through the digestive tract. No significant differences $(p>0.05)$ between diets were observed in the mean values obtained for total NAN entering into the small intestine, total $\mathrm{N}$ in urine, retained $\mathrm{N}$, proportionate disappearance apparently digested $\mathrm{N}$ within the small intestine and the whole digestive tract. It was nonsignificant net gain in the quantity of total $\mathrm{N}$ in the passage of the digesta through the stomach for all diets (1.107 \pm 0.035 of mean values). But there were

TABLE 2. THE QUANTITIES OF OM PRESENT IN THE FEED AND FAECES AND PASSING AT THE PROXIMAL DUODENUM AND TERMINAL ILEUM OF SHEEP

\begin{tabular}{|c|c|c|c|c|c|}
\hline & $\begin{array}{l}\text { Diet A } \\
\text { barley } \\
\text {-meat }\end{array}$ & $\begin{array}{l}\text { Diet B } \\
\text { barley } \\
\text {-soya }\end{array}$ & $\begin{array}{l}\text { Diet } C \\
\text { maize } \\
\text {-meat }\end{array}$ & $\begin{array}{l}\text { Diet D } \\
\text { maize } \\
\text {-soya }\end{array}$ & SEM \\
\hline \multicolumn{6}{|l|}{ Organic matter $(\mathrm{g} / 24 \mathrm{~h})$} \\
\hline in feed & 593.94 & 595.04 & 523.88 & 513.88 & - \\
\hline at proximal duodenum & $265.15^{a}$ & $258.16^{\mathrm{ab}}$ & $236.47^{b}$ & $232.77 \mathrm{~b}$ & 6.76 \\
\hline at terminal ileum & $148.41 \mathrm{ab}$ & $159.37^{a}$ & $136.50 \mathrm{abc}$ & $118.55^{\mathrm{c}}$ & 6.77 \\
\hline in faeces & $112.36^{\mathrm{a}}$ & $112.03^{a}$ & $89.26^{b}$ & $79.06^{b}$ & 6.58 \\
\hline $\begin{array}{l}\text { The proportionate } \\
\text { disappearance of } \\
\text { apparently digested OM }\end{array}$ & 0.8109 & 0.8118 & 0.8296 & 0.8462 & 0.009 \\
\hline \multicolumn{6}{|l|}{$\begin{array}{l}\text { The proportionate } \\
\text { disappearance of } \\
\text { apparently digested } \\
\text { OM }\end{array}$} \\
\hline 1) before small instestine & 0.6819 & 0.6981 & 0.6605 & 0.6464 & 0.015 \\
\hline 2) in small intestine & 0.2428 & 0.2040 & 0.2305 & 0.2630 & 0.019 \\
\hline 3) in caecum and colon & 0.0753 & 0.0979 & 0.1091 & 0.0906 & 0.029 \\
\hline
\end{tabular}

$\mathrm{a}, \mathrm{b}, \mathrm{c}$ Means that different superscripts in the same line are significantly different $(\mathrm{p}<0.05)$. different. $(\mathrm{p}<0.01)$. 
TABLE 3. THE QUANTITIES OF NITROGEN PRESENT IN THE FEED, FAECES AND URINE, AND PASSING AT THE PROXIMAL DUODENM AND TERMINAL ILEUM OF SHEEP

\begin{tabular}{|c|c|c|c|c|c|}
\hline & $\begin{array}{l}\text { Diet A } \\
\text { Barley } \\
\text {-Meat }\end{array}$ & $\begin{array}{l}\text { Diet B } \\
\text { Barley } \\
\text {-Soya }\end{array}$ & $\begin{array}{l}\text { Diet C } \\
\text { Maize } \\
\text {-Meat }\end{array}$ & $\begin{array}{l}\text { Diet D } \\
\text { Maize } \\
\text {-Soya }\end{array}$ & SEM \\
\hline \multicolumn{6}{|l|}{ Nitrogen $(g / 24 \mathrm{~h})$} \\
\hline in feed & 13.519 & 12.993 & 11.686 & 11.072 & - \\
\hline at proximal duodenum & 14.872 & 13.839 & 12.974 & 12.756 & 0.701 \\
\hline at terminal ileum & $5.411^{\mathrm{a}}$ & $4.701^{\mathrm{ab}}$ & $5.641^{\mathrm{a}}$ & $4.006^{b}$ & 0.236 \\
\hline in faeces & $3.387 \mathrm{a}$ & $2.786^{b}$ & $3.004 \mathrm{ab}$ & $2.521^{b}$ & 0.165 \\
\hline in urine & 7.128 & 6.761 & 6.027 & 4.905 & 0.839 \\
\hline $\begin{array}{l}\text { Proportionate dis- } \\
\text { appearance apparently } \\
\text { digested N }\end{array}$ & 0.7495 & 0.7856 & 0.7427 & 0.7723 & 0.014 \\
\hline $\mathrm{N}$ absorbed $(\mathrm{g} / 24 \mathrm{~h})$ & $10.132^{a}$ & $10.208^{a}$ & $8.682 \mathrm{~b}$ & $8.551^{b}$ & 0.196 \\
\hline $\mathrm{N}$ retained $(\mathrm{g} / 24 \mathrm{~h})$ & 3.004 & 3.447 & 2.655 & 3.646 & 0.684 \\
\hline $\begin{array}{l}\mathrm{N} \text { entering small } \\
\text { intestine (g/g N intake) }\end{array}$ & 1.100 & 1.066 & 1.110 & 1.152 & 0.042 \\
\hline $\begin{array}{l}\text { Proportionate dis- } \\
\text { appearance of apparently } \\
\text { digested } \mathrm{N} \text { in the small } \\
\text { intestine }\end{array}$ & 0.6370 & 0.6555 & 0.5592 & 0.6821 & 0.026 \\
\hline $\begin{array}{l}\text { Total non ammonia } N(N A N) \\
\text { entering small intestine } \\
(\mathrm{g} / 24 \mathrm{~h})\end{array}$ & 14.530 & 13.394 & 12.685 & 12.445 & 0.444 \\
\hline
\end{tabular}

${ }^{a, b}$ Means that different superscripts in the same line are significantly different $(p<0.05)$.

significant differences between diets in the quantities of total $\mathrm{N}$ leaving the small intestine $(\mathrm{p}<$ 0.01 ) and $\mathrm{N}$ absorbed in the whole digestive tract $(\mathrm{p}<0.01)$.

The quantities of total $\mathrm{N}$ leaving the small intestine for the diets containing meat and bone meal were significantly higher than for the diets containing soyabean meal. The quantities of apparently absorbed $\mathrm{N}$ in whole tract for the diets containing barley which is major carbohydrate source were significantly higher than for the diets containing maize as carbohydrate source.

Table 4 shows the amino acid composition and the total amino acid N(TAA-N), essential amino acid N(EAA-N) of the experimental diets. Comparison of the amino acid compositions of the four diets show similar pattern except glutamic acid and glycine. Diet $\mathrm{A}$ and Diet $\mathrm{C}$ including meat and bone meal contained proportionately more glycine but less glutamic acid than diet B and $\mathrm{D}$ including soyabean meal. This is due to the effect of low content of glycine in soyabean meal $(2.79 \%)$ than meat and bone meal $(22.38 \%)$. The amounts of TAA-N recovered accounted for only $415 \mathrm{~g} \mathrm{~N} / \mathrm{kg}$ total $\mathrm{N}$ in barley straw but accounted for $962 \mathrm{~g}$ in diet $\mathrm{A}, 973 \mathrm{~g}$ in diet B, $993 \mathrm{~g}$ in diet $\mathrm{C}$ and $905 \mathrm{~g} \mathrm{~N} / \mathrm{kg}$ total $\mathrm{N}$ in diet $\mathrm{D}$, respectively. EAA-N was shown lower contents than NEAA-N regardless of the different diets.

The amounts of the individual amino acid-N entering and leaving the small intestine are shown in table 5. Amino acids are grouped together in the tables according to the whether they are assumed to be essential (EAA: arginine, histidine, isoleucine, leucine, lysine, methionine, phenylalanine, threonine and valine) or non essential (NEAA: alanine, aspartic acid, glutamic acid, glycine, proline, serine and tyrosine). No values 
TABLE 4. THE AMINO ACID COMPOSITION AND THE TAA-N, EAA-N AND NEAA-N CONTENT OF THE DIET (G/100 G DM)

\begin{tabular}{llcccc}
\hline Amino acid & Barley straw & $\begin{array}{c}\text { Diet A } \\
\text { Barley-meat }\end{array}$ & $\begin{array}{c}\text { Diet B } \\
\text { Barley-soya }\end{array}$ & $\begin{array}{c}\text { Diet C } \\
\text { Maize-meat }\end{array}$ & $\begin{array}{c}\text { Diet D } \\
\text { Maize-soya }\end{array}$ \\
\hline Arginine & 0.056 & 1.10 & 0.70 & 1.01 & 0.98 \\
Histidine & 0.060 & 0.38 & 0.48 & 0.39 & 0.50 \\
Isoleucine & 0.100 & 0.53 & 0.70 & 0.53 & 0.92 \\
Leucine & 0.180 & 1.10 & 1.31 & 1.42 & 1.68 \\
Lysine & 0.070 & 0.74 & 0.75 & 0.62 & 0.72 \\
Methionine & 0.138 & 0.22 & 0.22 & 0.25 & 0.22 \\
Phenylalanine & 0.113 & 0.61 & 0.73 & 0.50 & 0.79 \\
Threonine & 0.125 & 0.61 & 0.67 & 0.58 & 0.68 \\
Valine & 0.140 & 0.83 & 0.90 & 1.07 & 0.98 \\
Alanine & 0.151 & 1.21 & 0.82 & 1.43 & 1.02 \\
Aspartic acid & 0.249 & 1.34 & 1.74 & 1.48 & 1.79 \\
Glutamic acid & 0.321 & 4.96 & 7.01 & 3.87 & 5.27 \\
Glycine & 0.144 & 2.78 & 0.83 & 3.31 & 0.78 \\
Proline & 0.127 & 1.72 & 1.67 & 1.67 & 1.08 \\
Serine & 0.111 & 0.74 & 0.87 & 0.86 & 0.86 \\
Tyrosine & 0.031 & 0.39 & 0.45 & 0.39 & 0.50 \\
TAA-N & 0.255 & 2.453 & 2.434 & 2.492 & 2.281 \\
EAA-N & 0.116 & 0.889 & 0.944 & 0.927 & 0.996 \\
NEAA-N & 0.139 & 1.564 & 1.490 & 1.565 & 1.285 \\
\hline TAA-N & $:$ & Total amino acid nitrogen, calculated as the sum of the N contents of the individual \\
Emino acid determined. & The assumption is made that arginine, histidine, isoleucine, lysine, methionine, phenyl- \\
EAA & $:$ & alanine, threonine and valine are essential & \\
NEAA-N & $:$ & This fraction comprises alanine, aspartic acid, glutamic acid, glycine, proline, serine and \\
& tyrosine. & & & & \\
& & & & &
\end{tabular}

are reported for cysteine and tryptophan. Table 6 gives the results relating to flows of total amino acid nitrogen (TAA-N) and essential and nonessential amino acid nitrogen (EAA-N and NEAAN) through the digestive tract.

There were no significant differences between diets for the quantities of TAA-N, EAA-N and NEAA-N passing at the duodenum and ileum except NEAA-N passing at the ileum $(\mathrm{p}>0.05)$. The quantities of NEAA-N passing at the ileum for the diets containing meat and bone meal were significantly higher than the diets containing soyabean meal $(p<0.05)$.

Therefore, it was observed that proportionate disappearances of apparently digested NEAA-N in the small intestine for the diets which is composed of meat and bone meal as a protein source were non-significantly lower than the diets with soyabean meal. No significant differences $(p>0.05)$ between diets were also observed in the mean values obtained for the quantities of TAA-N, EAA-N and NEAA-N entering small intestine compared to intakes (g AA-N in duodenum/g AA-N in feed intakes). The mean values for the EAA-N entering the small intestine for four diets were $1.265 \pm 0.0479$ and $0.888 \pm 0.1281$, respectively. There were net gains in the quantities of EAA-N in the passage of the digesta prior to the small intestine but net losses in the quantities of NEAA-N. The mean values for the proportionate disappearance apparently digested TAA-N, EAA$\mathrm{N}$ and NEAA-N within the small intestine for four diets were $0.692 \pm 0.449,0.702 \pm 0.0132$ and $0.682 \pm 0.075$, respectively.

In tables 7 and 8 the amounts of each amino acid entering the small intestine have also been expressed as proportions of the intake. Source of dietary protein had no effect on duodenal EAA 
TABLE 5. ESSENTIAL AMINO ACID NITROGEN (EAA-N) AND NONESSENTIAL AMINO ACID, NITROGEN (NEAA-N) OF DUODENAL AND ILEAL DIGESTA OF SHEEP (G/100G DM)

\begin{tabular}{|c|c|c|c|c|c|c|c|c|}
\hline & \multicolumn{4}{|c|}{ Duodenal digesta } & \multicolumn{4}{|c|}{ Ileal digesta } \\
\hline & Diet A & Diet B & Diet $C$ & Diet D & Diet A & Diet B & Diet C & Diet D \\
\hline Arginine & 1.39 & 1.39 & 1.32 & 1.25 & 0.57 & 0.43 & 0.61 & 0.52 \\
\hline Histidine & 0.79 & 0.81 & 0.68 & 0.77 & 0.44 & 0.48 & 0.53 & 0.60 \\
\hline Isoleucine & 1.19 & 1.35 & 1.31 & 1.48 & 0.79 & 0.86 & 0.67 & 1.09 \\
\hline Leucine & 1.82 & 2.16 & 2.35 & 2.78 & 1.03 & 1.02 & 1.13 & 1.40 \\
\hline Lysine & 1.86 & 1.81 & 1.71 & 1.80 & 0.90 & 0.72 & 0.88 & 0.95 \\
\hline Methionine & 0.38 & 0.55 & 0.51 & 0.58 & 0.10 & 0.09 & 0.18 & 0.30 \\
\hline Phenylalanine & 1.12 & 1.44 & 1.40 & 1.48 & 0.70 & 0.81 & 0.72 & 0.97 \\
\hline Threonine & 1.31 & 1.43 & 1.39 & 1.61 & 0.86 & 0.83 & 0.84 & 1.09 \\
\hline Valine & 1.44 & 1.52 & 1.86 & 1.74 & 0.78 & 0.75 & 0.79 & 0.96 \\
\hline Alanine & 1.76 & 1.67 & 2.11 & 2.07 & 1.09 & 0.94 & 1.16 & 1.23 \\
\hline Aspartic acid & 2.77 & 3.32 & 2.87 & 3.53 & 1.94 & 1.62 & 2.58 & 2.04 \\
\hline Glutamic acid & 3.76 & 5.13 & 4.58 & 4.75 & 2.50 & 2.03 & 2.38 & 2.76 \\
\hline Glycine & 2.38 & 1.37 & 2.54 & 1.65 & 2.23 & 0.98 & 2.27 & 1.22 \\
\hline Proline & 1.36 & 1.16 & 2.52 & 1.32 & 0.83 & 0.66 & 0.94 & 1.23 \\
\hline Serine & 1.87 & 1.34 & 1.53 & 1.54 & 0.89 & 0.78 & 0.90 & 1.01 \\
\hline Tyrosine & 0.84 & 1.01 & 1.00 & 1.10 & 0.49 & 0.55 & 0.33 & 0.69 \\
\hline TAA-N & 3.425 & 3.486 & 3.860 & 3.738 & 2.056 & 1.699 & 2.118 & 2.292 \\
\hline EAA-N & 1.612 & 1.725 & 1.749 & 1.816 & 0.859 & 0.791 & 0.875 & 1.089 \\
\hline NEAA-N & 1.813 & 1.761 & 2.111 & 1.922 & 1.197 & 0.908 & 1.243 & 1.203 \\
\hline
\end{tabular}

${ }^{1}$ Each value is the mean value of 4 sheep.

passage but on duodenal NEAA passage. There were no significant differences in duodenal amino acid flow between diets with the exception of aspartic acid and glycine. Aspartic acid in the duodenal digesta for the diets with soyabean meal was significantly higher than for the diets with meat and bone meal ( $p<0.05$ ). In contrast, glycine in the duodenal digesta for the diets with meat and bone meal was significantly higher than for the diets with soya $(\mathrm{p}<0.01)$. This is probably due to the dietary effect. It was observed higher content of glycine in meat and bone meal but lower content of aspartic acid than in soyabean meal (aspartic acid in soyabean meal and meat \& bone meal were 7.45 and $4.10 \%$, glycine in soyabean and meat \& bone meal were 2.79 and $22.38 \%$ respectively). The amounts of each amino acid in duodenal digesta, expressed as a proportion of the amounts ingested for the four diets were shown that there were net gains of EAA with the exception of arginine and NEAA with the exception of glutamic acid, glycine and proline prior to the small intestine. For all diets there appeared to be extensive destruction of dietary glutamic acid and proline prior to the small intestine. But there were no significant differences between diets for the amino acids expressed as a proportion of the intake with the exception of glycine.

The quantities for proportionate losses of individual amino acid within the small intestine are shown in table 9. These value are calculated as the difference between entering and leaving the small intestine, expressed as a portion of the amount entering. There were no significant losses of EAA within the small intestine between diets ( $p>0.05$ ) but significant losses of aspartic acid and glycine of NEAA between diets $(p<0.01)$. Disappearance of glycine for the diets with meat and bone meal was lower than the diets with soyabean meal. On all four diets, the mean values of the proportionate losses of methionine, alanine and lysine within the small intestine were $0.816+$ $0.04,0.767+0.04$ and $0.732+0.01$, respectively.

The value of duodenal $\mathrm{N}$ to the animal depends on quality as well as quantity. Ørskove et al. 
TABLE 6. THE QUANTITIES OF TAA-N, EAA-N AND NEAA-N (G/24 H) PRESENT IN THE FEED AND PASSING AT THE PROXIMAL DUODENUM AND TERMINAL ILEUM OF SHEEP

\begin{tabular}{|c|c|c|c|c|c|}
\hline & $\begin{array}{c}\text { Diet A } \\
\text { Barley-meat }\end{array}$ & $\begin{array}{c}\text { Diet B } \\
\text { Barley-soya }\end{array}$ & $\begin{array}{c}\text { Diet C } \\
\text { Maize-meat }\end{array}$ & $\begin{array}{c}\text { Diet D } \\
\text { Maize-soya }\end{array}$ & SEM \\
\hline \multicolumn{6}{|l|}{ TAA-N $(g / 24 h):$} \\
\hline in feed & 12.499 & 12.129 & 11.073 & 9.583 & - \\
\hline at proximal duodenum & 11.813 & 11.496 & 11.680 & 10.610 & 0.56 \\
\hline at terminal ileum & 3.987 & 2.821 & 3.859 & 3.310 & 0.31 \\
\hline $\begin{array}{l}\text { TAA-N entering small } \\
\text { intestine } \\
\text { (g/g TAA-N intake) }\end{array}$ & 0.948 & 0.879 & 1.067 & 1.123 & 0.09 \\
\hline $\begin{array}{l}\text { Proportionate } \\
\text { disappearance of } \\
\text { apparently digested } \\
\text { TAA-N in the small } \\
\text { intestine }\end{array}$ & 0.661 & 0.757 & 0.663 & 0.686 & 0.02 \\
\hline \multicolumn{6}{|l|}{ EAA-N $(g / 24 h):$} \\
\hline in feed & 4.315 & 4.732 & 4.147 & 4.192 & - \\
\hline at proximal duodenum & 5.566 & 5.729 & 5.290 & 5.150 & 0.43 \\
\hline at terminal ileum & 1.663 & 1.550 & 1.591 & 1.570 & 0.16 \\
\hline $\begin{array}{l}\text { EAA-N entering small } \\
\text { intestine } \\
(\mathrm{g} / \mathrm{g} \text { EAA-N intake })\end{array}$ & 1.329 & 1.222 & 1.273 & 1.235 & 0.04 \\
\hline $\begin{array}{l}\text { Proportionate } \\
\text { disappearance of } \\
\text { apparently digested } \\
\text { EAA-N in the small } \\
\text { intestine }\end{array}$ & 0.698 & 0.721 & 0.692 & 0.695 & 0.04 \\
\hline \multicolumn{6}{|l|}{ NEAA-N (g/24 h): } \\
\hline at proximal duodenum & 6.247 & 5.767 & 6.390 & 5.457 & 0.34 \\
\hline at terminal ileum & $2.324 a$ & $1.272^{b}$ & $2.240^{\mathrm{a}}$ & $1.742^{\mathrm{ab}}$ & 0.76 \\
\hline $\begin{array}{l}\text { NEAA-N entering small } \\
\text { intestine } \\
\text { (g/g NEAA-N intake) }\end{array}$ & 0.783 & 0.780 & 0.949 & 1.039 & 0.12 \\
\hline $\begin{array}{l}\text { Proportionate } \\
\text { disappearance of } \\
\text { apparently digested } \\
\text { NEAA-N in the small } \\
\text { intestine }\end{array}$ & 0.624 & 0.785 & 0.639 & 0.679 & 0.04 \\
\hline
\end{tabular}

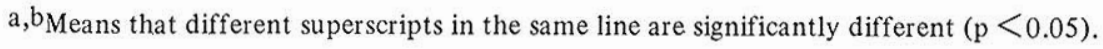

(1971) suggested that non $\mathrm{NH}_{3}-\mathrm{N}$ content of abomasul $\mathrm{N}$ increased with the amount of fish meal supplemented to a barley ration. However, we found very few differences between diets in NAN or EAA content of duodenal $\mathrm{N}$ (table 5).
The EAA content of duodenal $\mathrm{N}$ in this experiment was relatively constant even though the major nitrogen containing component of the diets was either soyabean meal or meat and bone meal. This result is in agreement with the findings of 
TABLE 7. THE QUANTITIES OF INDIVIDUAL EAA PASSING AT THE PROXIMAL DUODENUM (1) G/24 H, AND (2) AS A PROPORTION OF THE AMOUNTS INGESTED BY SHEEP

\begin{tabular}{|c|c|c|c|c|c|}
\hline Diet & $\begin{array}{c}\text { A } \\
\text { Barley-meat }\end{array}$ & $\begin{array}{c}\text { B } \\
\text { Barley-soya }\end{array}$ & $\begin{array}{c}\mathrm{C} \\
\text { Maize-meat }\end{array}$ & $\begin{array}{c}\text { D } \\
\text { Maize-soya }\end{array}$ & SEM \\
\hline \multicolumn{6}{|c|}{ Agrinine } \\
\hline (1) & 4.79 & 4.63 & 3.98 & 3.58 & 0.48 \\
\hline (2) & 0.894 & 0.988 & 0.898 & 0.900 & 0.12 \\
\hline \multicolumn{6}{|c|}{ Histidine } \\
\hline (1) & 2.72 & 2.74 & 2.04 & 2.53 & 0.34 \\
\hline (2) & 1.390 & 1.141 & 1.188 & 1.246 & 0.15 \\
\hline \multicolumn{6}{|c|}{ Isoleucine } \\
\hline (1) & 4.12 & 4.47 & 3.95 & 4.18 & 0.28 \\
\hline (2) & 1.515 & 1.284 & 1.631 & 1.260 & 0.15 \\
\hline \multicolumn{6}{|l|}{ Leucine } \\
\hline (1) & 6.30 & 7.12 & 7.14 & 7.90 & 0.58 \\
\hline (2) & 1.111 & 1.089 & 1.129 & 1.131 & 0.09 \\
\hline \multicolumn{6}{|l|}{ Lysine } \\
\hline (1) & 6.43 & 6.10 & 5.10 & 5.09 & 0.78 \\
\hline (2) & 1.746 & 1.679 & 1.870 & 1.728 & 0.29 \\
\hline \multicolumn{6}{|c|}{ Methionine } \\
\hline (1) & 1.31 & 1.80 & 1.55 & 1.65 & 0.38 \\
\hline (2) & 1.051 & 1.430 & 1.226 & 1.567 & 0.20 \\
\hline \multicolumn{6}{|c|}{ Phenylalanine } \\
\hline (1) & 3.87 & 4.70 & 4.21 & 4.15 & 0.38 \\
\hline (2) & 1.406 & 1.353 & 1.904 & 1.287 & 0.27 \\
\hline \multicolumn{6}{|c|}{ Threonine } \\
\hline (1) & 4.53 & 4.69 & 4.20 & 4.57 & 0.32 \\
\hline (2) & 1.427 & 1.321 & 1.586 & 1.615 & 0.14 \\
\hline \multicolumn{6}{|l|}{ Valine } \\
\hline (1) & 4.98 & 5.00 & 5.63 & 4.92 & 0.71 \\
\hline (2) & 1.179 & 1.135 & 1.207 & 1.222 & 0.07 \\
\hline
\end{tabular}

Oldham et al. (1977), Ben Ghedalia et al. (1978), and Mercer et al.(1980) which NAN and EAA content of duodenal $\mathrm{N}$ was similar pattern between the diets with soluble protein and insoluble protein source. It was observed that the EAA/TAA ratio in duodenal digesta is also relatively constant between diets. The individual EAA/TAA ratio in duodenal digesta was $0.477 \pm 0.019$ (table 10). This value is in a good agreement with the value $(0.48 \pm 0.02)$ reported by ARC (1984). The quantities of individual amino acid entering to the small intestine are shown in table 7 and 8 . The amounts of each amino acid in duodenal digesta were shown that there were net gains of EAA with the exception of arginine and NEAA with the exception of glutamic acid, glycine and proline prior to the small intestine. There appeared to an extensive destruction of dietary glutamic acid and proline. The large losses of proline and glutamic acid relative to the other amino acid prior to the small intestine have been noted by Clark et al. (1966), Leibholz (1972) and Overland (1980). 
TABLE 8. THE QUANTITIES OF INDIVIDUAL NEAA PASSING AT THE PROXIMAL DUODENUM G/24 H, AND (2) AS A PROPORTION OF THE AMOUNTS INGESTED BY SHEEP

\begin{tabular}{|c|c|c|c|c|c|}
\hline Diet & $\begin{array}{c}\text { A } \\
\text { Barley-meat }\end{array}$ & $\begin{array}{c}\text { B } \\
\text { Barley-soya }\end{array}$ & $\begin{array}{c}\mathrm{C} \\
\text { Maize-meat }\end{array}$ & $\begin{array}{c}\text { D } \\
\text { Maize-soya }\end{array}$ & SEM \\
\hline \multicolumn{6}{|l|}{ Alanine } \\
\hline (1) & 6.13 & 5.47 & 6.49 & 5.87 & 0.65 \\
\hline (2) & 0.992 & 1.319 & 1.038 & 1.373 & 0.14 \\
\hline \multicolumn{6}{|c|}{ Aspartic acid } \\
\hline (1) & $9.55 b c$ & $10.92^{a}$ & $8.67 \mathrm{c}$ & $10.01 \mathrm{ab}$ & 0.32 \\
\hline (2) & 1.375 & 1.250 & 1.301 & 1.330 & 0.09 \\
\hline \multicolumn{6}{|c|}{ Glutamic acid } \\
\hline (1) & 12.99 & 16.67 & 13.87 & 13.55 & 0.98 \\
\hline (2) & 0.536 & 0.534 & 0.872 & 0.710 & 0.17 \\
\hline \multicolumn{6}{|l|}{ Glycine } \\
\hline (1) & $8.06^{\mathrm{a}}$ & $4.48^{b}$ & $7.60^{a}$ & $4.68^{b}$ & 0.32 \\
\hline (2) & $0.601^{\mathrm{a}}$ & $1.080^{\mathrm{b}}$ & $0.579 a$ & $1.412^{b}$ & 0.13 \\
\hline \multicolumn{6}{|l|}{ Proline } \\
\hline (1) & 4.70 & 3.78 & 7.58 & 3.71 & 0.92 \\
\hline (2) & 0.588 & 0.541 & 1.083 & 0.815 & 0.14 \\
\hline \multicolumn{6}{|l|}{ Serine } \\
\hline (1) & 4.12 & 4.39 & 4.62 & 4.37 & 0.22 \\
\hline (2) & 1.089 & 1.006 & 0.980 & 1.220 & 0.09 \\
\hline \multicolumn{6}{|c|}{ Tyrosine } \\
\hline (1) & 2.90 & 3.36 & 3.02 & 3.11 & 0.31 \\
\hline (2) & 1.468 & 1.574 & 1.850 & 1.517 & 0.22 \\
\hline
\end{tabular}

a,b,c Values with different superscripts within the same culumn are significantly different $(\mathrm{p}<0.05)$.

Glutamic acid has been shown to be rapidly deaminated within the rumen being involved in transamination reactions (Lehninger, 1975; Lewis, 1955); 1) Oxaloacetate + L-glutamate $\rightleftharpoons \mathrm{L}$ aspartate $+\alpha$-keotglutarate 2) Pyruvate + L-glutamate $\rightleftharpoons$ L-alanine $+\alpha$-ketoglutarate 3) $\alpha$ ketoisocaproate + L-glutamate $\rightleftharpoons$ L-leucine $+\alpha$ ketoglutrarate 4) P-hydroxyphenyl pyruvate $+\mathrm{L}$ glutamate $\rightleftharpoons$ L-tyrosine $+\alpha$-ketoglutarate. Proline also can be converted to glutamic acid as following reactions, proline $\rightarrow$ Pyrroline 5, carboxylic acid $\rightarrow$ glutamic acid $\gamma$-semialdehyde $\rightarrow$ glutamic acid. Therefore, the large losses of proline and glutamic acid prior to the small intestine can probably be explained due to the transamination.

Absorption of amino acids in the small intestine are few differences between diets (table 6). The amounts of amino acids disappearing from the small intestine can be considered as the amounts available to the host animal with assumption that there is no significant absorption of amino acids from the rumen or from the caecum and colon (Armstrong and Annison, 1973). Values for the proportionate disappearance of TAA from the small intestine were in the range from 0.661 to 0.757 with a mean value of $0.692 \pm 0.0449$. This is in agreement with other workers. Coelho da Silva et.al. (1972) observed values for apparent absorption of TAA from the small intestine of sheep of $0.711,0.662$ and 0.698 for chopped, cobbed and pelleted alfalfa diets, respectively. Papasolomontos (1977) observed values from 
TABLE 9. THE QUANTITIES FOR PROPORTIONATE LOSSES OF INDIVIDUAL AMINO ACIDS WITHIN THE SMALL INTESTINE OF SHEEP ${ }^{1}$

\begin{tabular}{llllll}
\hline Amino acids & $\begin{array}{c}\text { Diet A } \\
\text { barley-meat }\end{array}$ & $\begin{array}{c}\text { Diet B } \\
\text { barley-soya }\end{array}$ & $\begin{array}{c}\text { Diet C } \\
\text { maize-meat }\end{array}$ & $\begin{array}{c}\text { Diet D } \\
\text { maize-soya }\end{array}$ & SEM \\
\hline Arginine & 0.761 & 0.814 & 0.718 & 0.776 & 0.04 \\
Histidine & 0.603 & 0.619 & 0.487 & 0.640 & 0.35 \\
Isoleucine & 0.632 & 0.598 & 0.687 & 0.620 & 0.05 \\
Leucine & 0.682 & 0.717 & 0.699 & 0.743 & 0.05 \\
Lysine & 0.723 & 0.740 & 0.734 & 0.729 & 0.04 \\
Methionine & 0.856 & 0.854 & 0.795 & 0.759 & 0.06 \\
Phenylalanine & 0.639 & 0.656 & 0.687 & 0.654 & 0.05 \\
Threonine & 0.632 & 0.643 & 0.625 & 0.651 & 0.04 \\
Valine & 0.692 & 0.696 & 0.718 & 0.712 & 0.04 \\
Alanine & 0.645 & 0.653 & 0.624 & 0.696 & 0.07 \\
Aspartic acid & $0.604 \mathrm{a}$ & $0.708 \mathrm{a}$ & $0.473 \mathrm{~b}$ & $0.703 \mathrm{a}$ & 0.03 \\
Glutamic acid & 0.633 & 0.762 & 0.630 & 0.697 & 0.03 \\
Glycine & $0.455 \mathrm{a}$ & $0.562 \mathrm{~b}$ & $0.460 \mathrm{a}$ & $0.621 \mathrm{~b}$ & 0.03 \\
Proline & 0.643 & 0.615 & 0.745 & 0.508 & 0.06 \\
Serine & 0.661 & 0.646 & 0.632 & 0.662 & 0.05 \\
Tyrosine & 0.668 & 0.657 & 0.765 & 0.605 & 0.03 \\
\hline
\end{tabular}

${ }^{1}$ These values are calculated as the difference between amounts entering and leaving the small intestine, expressed as a portion of the amount entering.

$a, b, c$ Values with different supperscripts within the same culumn are significantly different $(\mathrm{p}<0.01)$.

TABLE 10. ESSENTIAL AMINO ACID PROPORTION IN DUODENAL DIGESTA ${ }^{1}$

\begin{tabular}{ccccccccccc}
\hline \multirow{2}{*}{ Amino acids } & Arg. & Hist. & Iso. & Leu. & Lys. & Met. & Phe. & Thr. & Val. & EAA/TAA \\
\hline Diet A & 0.12 & 0.07 & 0.11 & 0.16 & 0.03 & 0.16 & 0.10 & 0.12 & 0.13 & 0.471 \\
B & 0.11 & 0.07 & 0.11 & 0.17 & 0.04 & 0.15 & 0.11 & 0.11 & 0.12 & 0.498 \\
C & 0.10 & 0.05 & 0.10 & 0.19 & 0.04 & 0.14 & 0.11 & 0.12 & 0.13 & 0.453 \\
D & 0.09 & 0.07 & 0.11 & 0.20 & 0.04 & 0.15 & 0.11 & 0.12 & 0.13 & 0.485 \\
Mean & 0.11 & 0.06 & 0.11 & 0.18 & 0.04 & 0.15 & 0.11 & 0.12 & 0.13 & 0.477 \\
\hline
\end{tabular}

${ }^{1}$ Values for individual amino acids are expressed as proportions $(\mathrm{g} / \mathrm{g})$ of the total essential amino acids (EAA) mixture.

0.638 to 0.725 for the processed barley diets with hay and Overland (1980) reported from 0.688 to 0.785 with a mean value of $0.738+$ 0.0066 for the rolled barley-hay diet with or without soyabean meal. Mean values for apparent absorption of EAA and NEAA in the small intestine for all diets were $0.702 \pm 0.013$ and $0.682 \pm$ 0.073 , respectively (table 6 ). These values are similar results reported by Armstrong et al. (1977) and Overland (1980) which the apparent absorption of EAA from the small intestine is consistantly higher than that of NEAA $(0.740 \pm$ 0.008 for EAA and $0.728 \pm 0.007$ for NEAA).

Tamminga (1983) pointed out that not only to apparent absorption from the small intestine but also the amino acid composition of protein entering the small intestine seems fairly constant. This may be the result of the contribution of microbial protein with a rather constant amino acid composition. 
The difference between apparent and true amino acid absorbability will depend on the amount of amino acid entering the duodenum. At the present time, it is very difficult to determine true digestibility in the small intestine, which are confounded by species, type of diet, site of measurement, of input in relation to endogenous secretion of amino acid $\mathrm{N}$ into the abomasum and proportion of microbial to undegraded dietary protein entering the small intestine (ARC, 1984).

Simple assessments of relative needs based upon comparisions of the pattern of EAA supply at the duodenum with EAA deposited in the body suggest that leucine, lysine and histidine are likely to be among those most limiting of growth but such comparisons may be misleading because of the paucity of information on the relative efficiency of use of different EAA. The frequent experimental finding that methionine is a limiting amino acid in ruminant nutrition may be because methionine is used for purposes other than protein synthesis (ARC, 1984). But we couldn't calculate limiting amino acids in those experimental diets because we couldn't find out the amino acid composition of whole body of sheep from references.

\section{Literature Cited}

Agricultural Research Council. 1984. The nutrient requirements of ruminant livestock. Supplement No. 1. Commonwealth Agricultural Bureaux.

Armstrong, D. G., and E. F. Annison. 1973. Amino acid requirements and amino acid supply in the sheep. Proceedings of the Nutrition Society 32:1107-1113.

Armstrong, D. G., G. P. Sawage, and D. G. Harrison. 1977. In Proc. 2nd International symposium on protein metabolism and nutrition. p. 25, Flevohof, Netherlands.

Ben-Ghedalia, D., N. P. McMeniman and D. G. Armstring. 1978. The effect partially replacing urea nitrogen with protein $\mathrm{N}$ on $\mathrm{N}$ capture in the rumen of sheep fed a purified diet. Brit. J. Nutr. 39:37-44.

Beever, D. E., D. G. Thomson, E. Pfeffer and D. G. Armstrong. 1971. The effect of drying and ensiling grass on its digestion in sheep. Brit. J. Nutr. 26: 123-124.

Clarke, E. M. W., G. M. Ellinger and A. T. Phillipson. 1966. The influence of diet on the nitrogenous components passing to the duodenum and through the lower ileum of sheep. Proceedings of the Royal Society B 166:63:79.

Coehlo Da Silva, J. F., R. C. Seeley, D. E. Beever, T. H. D. Prescott and D. G. Armstrong. 1972. The effect in sheep of physical form and stage growth on the sites of digestion of a dried grass. 2. Sites of nitrogen digestion. Brit. J. Nutrition 28:357-371.

Lewis, D. 1955. Br. J. Nutr. 9:215. Cited form Ph.D. thesis of M. A. Overland 1980. University of Newcastle Upon Tyne.

Lehninger, A. L. 1975. Biochemistry (2nd Ed.) pp. 562563. Worth Publishers, Inc. New York.

MacRae, J. C. and D. G. Armstrong. 1969. Studies on intestinal digestion in the sheep. 1. The use of chromic oxide as an indigestible marker. Brit. J. Nutr. 23:15-23.

McMeniman, N. P. and D. G. Armstrong. 1979. The flow of amino acids into the small intestine of cattle when fed heated and unheated beans (Vicia faba). J. Agric. Sci. Camb. 93:181-188.

Mercer, J. R. and E. F. Annison. 1976. Utilization of nitrogen in ruminants. In D.J.A. Cole, K. N. Boorman, P. J. Buttery, D. Lewis, R. J. Neale and H. Swan (Ed) Protein Metabolism and Nutrition. Butterwoth Inc. Boston, MA. U.S.A.

Oidham, J. D., P. J. Buttery, H. Swan and D. Lewis. 1977. Interactions between dietary carbohydrates and nitrogen and digestion in sheep. J. Agri. Sci. Camb. 89:467-479.

Ørskov, E. R., C. Fraser and I. McDonald. 1971. Digestion of concentrated in sheep. 2. The effect of urea or fish meal supplementation of barley diets on the apparent digestion of protein, fat, starch and ash in the rumen, the small intestine and the large intestine, and calculation of volatile fatty acid production. Brit. J. Nutr. 25:243-252.

Overland, M. A. 1980. Some studies in amino acid uptake in ruminants. Ph.D. Thesis, University of Newcastle Upon Tyne.

Papasolomontos, S. A. 1977. Studies on the digestion of heat-processed cereals by the adult sheep. Ph.D. Thesis Department of Agricultural Biochemistry. University of Newcastle Upon Tyne.

Tamminga, S. 1983. Recent Advances in our knowledge on protein digestion and absorption in ruminants. In 4 th Int. Symp. Protein metabolism and nutrition edited by INRA Publ. Clemont-Ferrand (France) pp.263-287.

Williams, C. J., D. J. David and O. Iismaa. 1962. Determination of chromic oxide in faeces samples by atomic absorption spectrophotometry. J. Agric. Sci. Camb. 59:381-385. 
